\title{
A Study on Overseas Investment Opportunities of Chinese Iron and Steel Enterprises from the Perspective of Globalization Strategy*
}

\author{
Wuyi Wang1, Caixia Zheng1, Peng Liu² \\ ${ }^{1}$ School of Business, Anhui University of Technology, MaAnshan, China \\ ${ }^{2}$ Shanghai Zhengsheng Investment Co, Ltd., Shanghai, China \\ Email:wwy66@ahut.edu.cn
}

Received 27 April 2016; accepted 13 May 2016; published 16 May 2016

Copyright (C) 2016 by authors and Scientific Research Publishing Inc.

This work is licensed under the Creative Commons Attribution International License (CC BY). http://creativecommons.org/licenses/by/4.0/

\section{(c) (i) Open Access}

\begin{abstract}
The global steel industry is a highly internationalized industry, globalization strategy is the inevitable choice of Chinese steel enterprises to improve the international competitiveness, and many factors make it feasible for Chinese iron and steel enterprises to implement globalization strategy. This paper made an analysis on the overseas investment opportunities of Chinese steel enterprises from the perspective of globalization strategy, involving the resource-based commodity investment, the establishment of overseas production bases and R\&D center, controlling trade channels and building strategic alliance, then sketched out the globalization strategy implementation framework of Chinese iron and steel enterprises.
\end{abstract}

\section{Keywords}

Chinese Iron and Steel Enterprises, Overseas Investment Opportunities, Globalization Strategy

\section{The Necessity and Feasibility of Implementing Globalization Strategy for Chinese Iron and Steel Enterprises}

Globalization strategy means that the multinational corporations decentralize and deploy links and functions of the value chain by making use of local comparative advantages of different countries and regions from a global

\footnotetext{
*This research was financially supported by the Cooperation Research Foundation of Anhui University of Technology with Shanghai Zhengsheng Investment Co, Ltd.
}

How to cite this paper: Wang, W.Y., Zheng, C.X. and Liu, P. (2016) A Study on Overseas Investment Opportunities of Chinese Iron and Steel Enterprises from the Perspective of Globalization Strategy. Open Journal of Social Sciences, 4, 74-86. http://dx.doi.org/10.4236/iss.2016.45011 
viewpoint, integrate them organically, implement comprehensive and integrated management, make efforts to reduce production and operating costs in order to obtain long-term, stable global competitive advantage, and maximize the global efficiency (Wang Jiajie, 2010) [1], it consists of strategic thinking, strategic target, strategic guarding principle, strategic policy, strategic organization(Han Xuegong, 2004) [2]. Deepika Jindal, Chandan Jee, Rajiv R. thakur (2011) made a research on the Nissan's “go-global” strategy, concluded that the multinational corporations didn't use same tactics across all the countries, which was adjusted by the external environment as well as customer requirement [3].

With the accelerated integration of global economy, the enterprises are unable to adapt themselves to the pace of the times by sticking to the traditional development model of localization, so the globalization strategy gradually enters into the enterprises' field of vision. Through their twenty-year study involving over two hundred corporations, Anil K. Gupta, Vijay Govindarajan, Haiyan Wang (2008) concluded that a company want to create and maintain its position as a globally dominant player, it should be in the industrial lead in recognition of global market opportunities, the formation of global competitive advantage and global field of vision etc [4]. Considering the actual situation of global iron and steel industry, it is the inevitable trend to implement globalization strategy, the implementation of globalization strategy is the necessary and feasible measure to realize the rapid development for Chinese iron and steel enterprises (refer with: Figure 1).

\subsection{The Necessity of Implementing Globalization Strategy for Chinese Iron and Steel Enterprises}

First, the low degree of globalization of Chinese iron and steel enterprises must be changed. Global steel industry is a highly internationalized industry, although Chinese iron and steel enterprises have made unrelenting global exploration, but the substantive breakthrough at the globalization didn't occur. Chinese iron and steel enterprises hesitate to press forward at the low degree of globalization for a long time: the internationalization of the products is still the main form of globalization; it is very difficult to make progress in overseas manufacturing investment; the expansion and optimization of global value chains is very weak. Although China is the world's largest steel producer, but no Chinese steel enterprises including Baosteel can be called "Multinational Corporation”, the qualified multinational corporations are the steel enterprises in Europe, America, Japan and South Korea, there is a big gap between Chinese steel enterprises and the world-renowned steel enterprises in the international competitiveness. Xiaoqi Cao, Youwei Lai (2012) pointed out that the global steel industry remain active in cross-border investments, merger and acquisition, the concept of globalization must be established for the development of the steel industry, so the implementation of "Going Out" strategy is an inevitable choice of steel enterprises as to adapt themselves to the trend of economic globalization and realize sustainable development [5]. In order to make China a steel power, globalization inevitably become a target in the future development of Chinese steel enterprises. During the period of “China's New Normal”, the Chinese steel enterprises should take the strategic initiative, change development concepts positively, cultivate global thinking, find the new investment opportunities, accelerate the overseas investment, and enhance the dominance in international market.

Second, the Chinese enterprises must take measures to solve the problems like overcapacity, shrinking profit margins. Nowadays, Chinese domestic economic growth is slowing down, facing the trend of transformation and upgrading, which further highlights steel overcapacity. On the basis of statistics, in 2014 China's the crude steel output is about 820 million tons, but steel demand is about 710 million tons, oversupply situation is distinct,

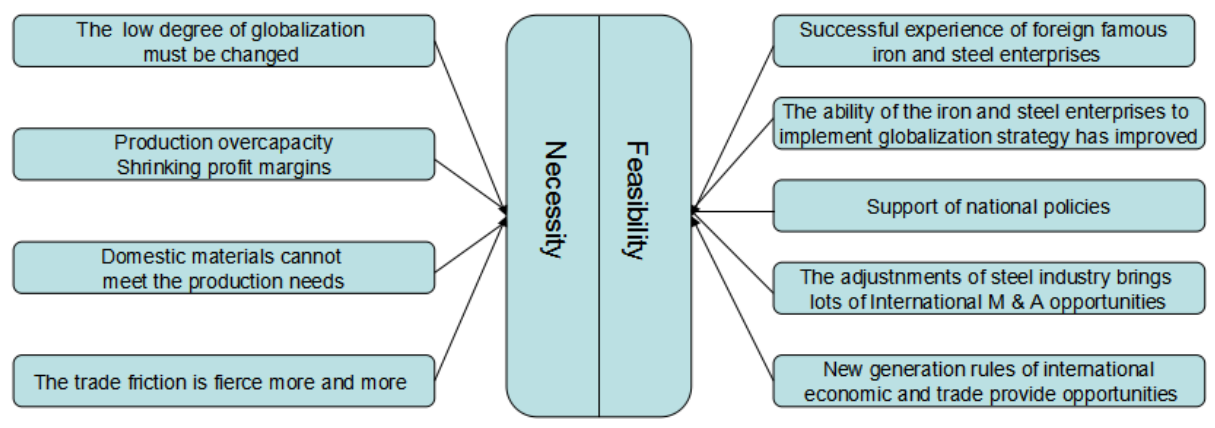

Figure 1. The necessity and feasibility of implementing globalization strategy. 
capacity utilization needs to be improved. In December 2014, China Metallurgical Industry Planning and Research Institute released "2015 Chinese steel demand forecasting research", it predicted that the steel demand, the crude steel output of China in 2015 will reach 720 million tons, 834 million tons ${ }^{1}$, so it's an important task to reduce inventories and overcapacity for Chinese steel enterprises in the future. Furthermore, Chinese steel enterprises are all facing the pressure of shrinking profit margins because steel is homogeneous product. In this case, Chinese steel enterprises should implement the "Going Out” strategy positively, make full use of "two kinds of resources, two markets "to deal with excess capacity effectively and change the situation of low profits.

Third, domestic steel production is highly dependent on foreign raw materials. Steel industry belongs to resource-intensive industry; its development is separated from the stable supply of upstream raw materials. Xiaoxi Zhang (2013) pointed out that the steel industry's future success will depend on effective upstream material industry [6], but at present, Chinese iron and steel enterprises are facing the problem of shortage of raw materials. For example, iron ore is an important raw material in the process of steel production, although China is rich in iron ore resources, lean ore reserves account for $80 \%$ of the total, the average ore grade is not high, Overall iron ore self-sufficiency rate of Chinese steel enterprises is less than $20 \%$ over the years, domestic iron ore can't meet the needs of the domestic steel production. This has made Chinese steel production is heavily dependent on imported ore, then China has become the world's largest importer of iron ore since 2003, and external dependence is still more than $60 \%$ in recent years. To solve this problem, Chinese iron and steel enterprises should invest in the region which is rich in resources, increase the proportion of overseas interest mine, obtain a stable supply of iron ore And enhance China's bargaining power in iron ore trade.

Fourth, the trade friction related to Chinese exported steel products is fierce more and more. According to the statistics, China's steel exports exceeded 90 million tons in 2014, reached a new record, while Chinese steel products suffered about 84 trade remedy investigations, an increase of 37 cases or an increase of $78.72 \%$ over 2013. Anti-dumping and countervailing is still the main form of trade remedy investigations, account for $99.98 \%$ of the whole ${ }^{2}$. The traditional market such as the United States, Australia, and EU is still the main force of 15 countries or regions that initiated investigations, but trade friction gradually spread to emerging market, Vietnam, India, Guatemala, Malaysia, and Thailand have taken safeguard measures against imported steel. This indicates a further deterioration of China's steel product export environment; exports of steel products are becoming more and more difficult. The steel enterprises implementing globalization strategy can avoid trade friction effectively, save transportation costs and reduce all kinds of cost by establishing overseas production bases or joint enterprises. Besides, implementing globalization strategy can improve export competitiveness of Chinese steel product so as to widen profit margins in the case of appreciation of RMB.

\subsection{The Feasibility of Implementing Globalization Strategy for Chinese Iron and Steel Enterprises}

First, from a worldwide perspective, well-known foreign steel enterprises have made great achievements by implementing globalization strategy and have accumulated rich experience in the global practice, Chinese steel enterprises can learn much from them. Bing Xiang (2007) pointed out that Mittal Steel attached great importance to global resource integration and became the global steel giant through extensive international mergers and acquisitions [7]. ShaoBing Xu (2014) pointed out that POSCO has pursued global strategic layout actively since the 1990s, the main overseas targets have been expanded to Australia, India, Vietnam, Indonesia and other emerging economies except China and Japan, and also made exploits in Brazil, Mexico, the United States, Poland, Turkey, Zimbabwe and other European and African countries, its international competitiveness have been greatly strengthened through global layout, it became the most competitive steel manufacturers in the world [8]. The practice of foreign iron and steel enterprises in the layout of globalization gives a good demonstration to Chinese steel enterprises, this is valuable reference, be useful for Chinese steel enterprises in determining the global strategic goals, formulating a global strategy policy.

Second, Chinese steel enterprises have made much exploration for implementation of globalization; the global competitiveness has increased gradually. For example, in 2002, Baosteel established Baohuarui mining company by cooperating with Brazil's companhia Vale do Rio Doce (CVRD), created first overseas investment of Chinese iron and steel enterprises to establish a mining company, henceforward it continued to invest in upstream

\footnotetext{
${ }^{1}$ Data source: The website of China Metallurgical Industry Planning and Research Institute, http://www.steelplanning.cn/
}

${ }^{2}$ Data source: http://www.glinfo.com/ 
and downstream industry, successively extended to Australia, Southeast Asia, Americas, Middle East, India and other many countries and regions, its overseas branches and cooperation projects are over the world. Baosteel is an outstanding representative of Chinese iron and steel enterprises in globalization development. In 2014, Under the depression of the whole steel industry, Chinese iron and steel enterprises extricate themselves from the difficult position and speed up "Going Out", Masteel merged French Wharton high-speed railway parts company, Hebei Iron and Steel Group held Swiss Degao international trade holding company, all this revealed the strength and boldness of China's steel enterprises that conduct the layout of globalization. Chinese steel enterprises Chinese steel enterprises such as Tangsteel, Shougang Group, Ansteel, Wusteel have made much significant progress in their practice of globalization, thus it can be seen that the ability of Chinese steel enterprises to implement globalization strategy has been improved.

Third, the national policy provides a strategic opportunity for Chinese steel enterprises to fight against "The winter of steel industry". In the construction of "One Belt, One Road and One Continent" the interconnection of infrastructure is the basic condition for the integration and development of all countries in these regions, so infrastructure construction must be the top priority of the preliminary work [9]. The construction of railways, airports, ports, nuclear power, telecommunications, energy facilities and other infrastructure in the more than 60 countries and regions will consume a large number of steel products, soon afterwards the development of related industries will also drive multiple industry demand for steel, this provides the opportunity for Chinese steel enterprises to transfer excess capacity through the implementation of globalization strategy. In addition, the steel production capacity is not enough to meet the needs of domestic economic construction in some countries and regions along "One Belt, One Road”, Chinese iron and steel enterprises can go abroad, make use of the geopolitical advantage, strategic partnership relations, establish iron and steel production bases and trading companies, strengthen the production of high-end steel products, to better meet the local market demand.

Fourth, the decline of steel industry resulted in excess capacity, at same time also eliminated backward production capacity, coinciding with global steel industry adjustment, many medium and small iron and steel enterprises and steel traders have withdrawn from the competition, this provides an opportunity for Chinese iron and steel enterprises to carry out extensive cross-border mergers and acquisitions. The benefits of cross-border M\&A are mainly reflected in two aspects: make full use of the existing advantage accumulated by the original enterprises to shorten the process of international exploration, bring huge scale effect and cost advantage being due to the synergistic effect of $\mathrm{M} \& \mathrm{~A}$, so as to improve the enterprises' international competitiveness. For example, in June 2014, Masteel intended to purchase French Wharton high-speed railway parts company at the price of 13 million Euro, which be approved by the local French court. It helps the Masteel master Wharton's advanced high-speed rail wheel technology and obtain a new international competitive advantage depending on Wharton's extensive overseas sales channels and successful sales experience.

Fifth, China is an active participator in the formulation of new generation rules in global economy and trade, has made efforts to promote multilateral trade negotiations and strengthen its discourse power, which bringing a significant boost in global economy and trade governance, although the United States, the European Union, Japan and other developed countries and regions trying to become the leader in the formulation of new generation rules in global economy and trade, resulting in external pressure to the institutional standardization and reform of developing countries including China [10], this provides strong support on the implementation of globalization strategy for Chinese enterprises. More importantly, the new international economic and trade rules promote the liberalization of trade and investment, global market open further while policy space is broadening, all of these are conducive to the development of Chinese steel enterprises, Chinese steel enterprises can participate in international competition, accelerate the overseas investment, continuously enhancing the degree of globalization.

\section{Overseas Investment Opportunities of Chinese Iron and Steel Enterprises from the Perspective of Globalization Strategy}

The implementation of globalization strategy is the key strategy for Chinese iron and steel enterprises to adapt to the international competition situation and achieve long-term development. Furthermore, the development of economic globalization and integration of the world also provide opportunities for the steel enterprise to go abroad and to carry out the strategic layout of globalization [11]. However, globalization is a gradual process, globalization of the steel industry can't be realized overnight. The steel enterprises need to judge the hour and 
size up the situation, grasp the global investment opportunities accurately, choose the right area and find out the right way, then explore continuously and practice in depth. What follows in the passage is an analysis on the overseas investment opportunities of Chinese steel enterprises in five aspects.

\subsection{The Opportunities of Investing in the Resource-Based Commodities}

The energy consumption of the steel industry is huge, stable supply of raw materials such as iron ore, coal and other raw materials is essential for the steel production, Posco, Arcelor Mittal, NSSC, JFE and other international large-scale iron and steel enterprises are relatively successful in dealing with this problem. Stressing on resource controlling is the consensus of iron and steel enterprise. Facing with the problem that domestic resources can't meet the needs of production, Chinese iron and steel enterprises should pay attention to the investment of the resource-based commodities to improve the resource security effectiveness during the process of globalization.

Take the investment in iron ore resources for example, the price of iron ore have been falling since the beginning of 2014, Platts iron ore index of $62 \%$ fell to $\$ 71.75$ from $\$ 134.50$ per ton, dropped $53.35 \%$, and there’s a continuing downward trend (refer with: Figure 2). In the case of continued decline in mine prices, BHP, Vale, Rio Tinto and FMG can still make profit with low production costs and scale economy advantages, however the small and medium-sized mining enterprises with high costs were overwhelmed and forced to stop production or change main business. In July 2014, Australia Sherwin Iron Ore Co (Sherwin Iron) first announced bankruptcy; In September, the Western Desert Resources Company (Western Desert Resources) had become Australia's second collapse of small miners due to unable to come to an agreement with Macquarie in the capital arrangement of Roper Bar iron ore. Australia Atlas Iron Ore Co, Grange resource companies and Gibson Mountain Iron Ore Co and other small and medium mines are also generally facing the survival pressure according to the trend of the mine price [12]. In addition, a number of mines in Brazil, India, Africa and other areas also have to stop production or close down.

More notable is that foreign small and medium enterprises have closed down under cost pressure, which provides best opportunity for Chinese steel enterprises to invest in overseas iron ore resources due to the small investment resistance and the low investment cost. In general, the following two ways can serve as reference: (1) Chinese iron and steel enterprises make use of capital advantage to share in the mines located in the regions where hold rich iron ore resources, such as Australia, Brazil and other areas. Generally, these mines have good qualification, while trapped in business difficulties. Cooperating with the regions to exploit these mines, with the help of adding investments and acquiring shares and other ways Chinese iron and steel enterprises increase its stock, pursue the holding rights and expand the quantity of overseas equity mines. This can improve the international market share of China's equity mines and strengthen the discourse power of steel enterprises in the pricing mechanism of iron ore, avoiding market oligopoly and monopoly pricing of the mining tycoons. (2) Chinese iron and steel enterprises merge and purchase some closed mining enterprises that still have production potentialities, conduct enterprise restructuring and integration of resources, strengthen management, make use of the existing production equipment and maximize the resource potential and improve their own overseas mines production, to avoid excessive dependence on imports of mine. Since India cracks down on illegal mining, in major iron ore producing provinces, such as Karnataka, Goa, Odisha and Jharkhand, mining has been banned, many domestic mine went out of business, this country faces a serious shortage of iron ore, the advantage of rich iron

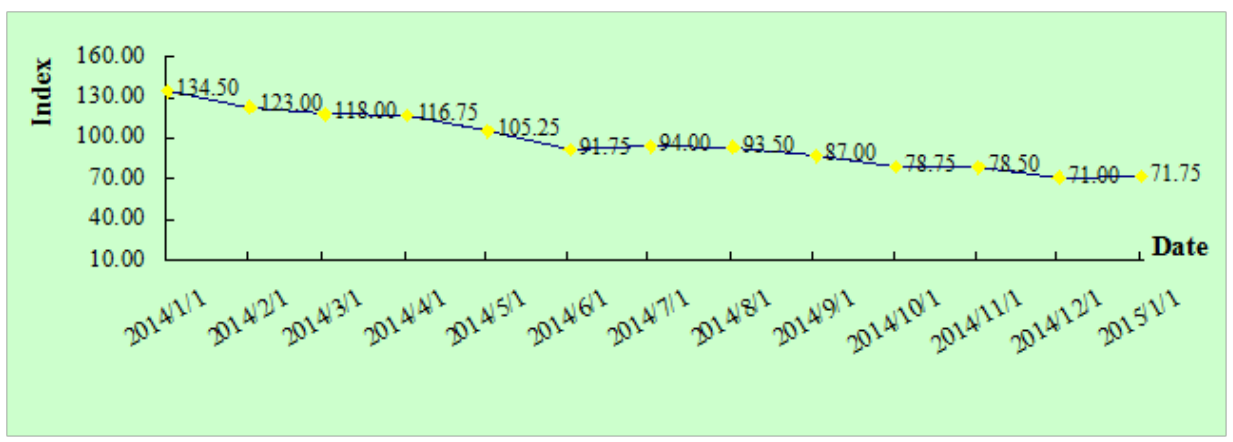

Figure 2. Platts iron ore index of 62\% in 2014. Source: http://www.96369.net/ 
ore resources exist no longer, there is up to 45 million tons of iron ore gap within the next three years. So in addition to meet their own demands, Chinese iron and steel enterprises will also have broad market prospects due to strengthen the resource-based commodities investment.

Similarly, Chinese iron and steel enterprises should observe the fact that Africa is the only region in the world that mineral resources being not yet fully developed and utilized, Iron ore resources are mainly distributed in the Republic of South Africa, the Democratic Republic of Congo, Gabon, Guinea, Mauritania, Morocco, Egypt, Zimbabwe, Tanzania, Liberia and Angola [13]. Furthermore, the ore resources have the characteristics of high iron content, opencast mining, low cost, all of those provide a unique condition for mass iron and steel production. Hence, Chinese iron and steel enterprises should take the initiative to increase investment in African iron ore resources, providing convenience for establishing steel production base and building industrial chain in Africa. In addition, Russia, Canada, and other areas are also rich mineral resource areas, Chinese iron and steel enterprises should strengthen cooperation with these regions by flexibly making use of geographical, economic advantages and diplomatic relations to realize diversification of choice, further improve resources supply capacity, then get rid of the traditional dependence on three mining tycoons gradually.

\subsection{The Opportunities of Establishing the Overseas Production Bases}

One of the motivations of enterprises to carry out the strategy of globalization is making full use of the advantages in different regions, and realizing the best allocation of resources globally. For that reason, establishing production bases in the regions that having strong consumption demands is an important way for steel enterprises' to explore the globalization. In the circumstances of weak domestic demands and low steel prices, Chinese iron and steel enterprises pay close attention to the potential demands for steel products in emerging market countries and regions, need a careful analysis on the resource distribution and market situation, it is the necessary measure that establishing overseas production bases and breaking through the development bottleneck.

In May 2014, at the beginning of holding power, India mode's new government regarded economic development as the core task, the large-scale infrastructure construction projects have been started, bring the huge demands for steel products. But in recent years, because illegal exploitation of iron ore being banned in India, mining is very limited, bring a serious shortage of domestic iron ore, it is restricted to improve productivity for domestic iron and steel enterprises, the demands for imports of steel are increasing. Similarly, in recent years, Africa's economic development is strong, attracted a large number of enterprises to invest there. Being jointly published by the United Nations Economic Commission for Africa and the African Union, <2014 African economic report> called for African governments to develop effective industrial policy, regard the industry as the main engine of economic development, that means a huge demand for steel behind the country's economic construction and industrial development. However, although Africa is rich in iron ore resources, local production of iron and steel enterprises generally face the lack of funds, backward technology, shortage of talents, domestic steel production is far from being able to meet the growing market demands. Seen from Figure 3, from 1997 to 2013 Africa crude steel production were lower than yearly apparent steel consumption, from the view of the upward trend in the data, the consumption growth rate was far faster than the crude steel production, there is a big gap in steel production and with passing time, the gap proportion will be more and more big, a huge steel demand needs to be satisfied.

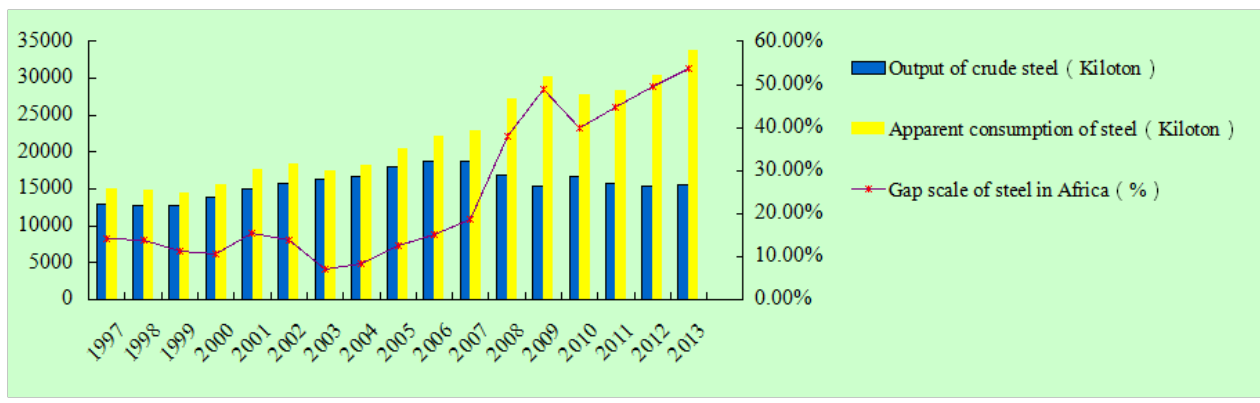

Figure 3. African output of crude steel, apparent consumption and gap scale in 1997-2013. Sources: (1) http://www.worldsteel.org/zh/; (2)<Steel Statistical Yearbook (2005-2014)> (International Iron and Steel Institute). 
From the perspective of market demand, Chinese iron and steel enterprises can regard India and Africa as the priority in establishment of overseas production bases and play their own accumulated technology and talent advantages in the manufacturing sector, try to set up steel production base in India, Africa and other emerging market countries and regions, strengthen the iron and steel production efforts, shorten geographical distance between production and consumption, meet the rapid growth of steel consumption market. Africa has about $33 \%$ of the global mineral reserves [14], owns more opencast mining, duo to the low wage level, possesses the natural advantages of low production cost and high average mineral quality, India is also the region that high grade ore being widely distributed in, owns more opencast mining, the rich iron ore resources provide great convenience for the construction of production bases and the enterprises can save employment costs by hiring plenty of cheap local labors. These developing countries' markets are not saturated, accompanied by the rapid development of economy, infrastructure, housing, cars and other fields will bring new investment opportunities [15] for the iron and steel enterprises, the future development of steel enterprises is very impressive, it's wise action that actively establishing overseas production bases to adapt to the development situation and trend. On 10 September 2014, in Beijing Hebei Iron and Steel Group and South African Industrial Development Corporation, Sino-Africa development funds signed <the South African iron and steel project cooperation memorandum of understanding>, which marked the construction of 500 million tons of steel project being officially launched due to the investment of Hebei Iron and Steel Group in South Africa, This is also the largest scale, whole process overseas iron and steel investment project leaded by Chinese iron and steel enterprises. This is the latest practice in the development of globalization of Hebei iron and steel Group, which formed a strong enlightening to the overseas investment of other Chinese iron and steel enterprises.

From the view of regional strategy, under “One Belt, One Road” strategy Chinese iron and steel enterprises can conduct important strategic deployment in Central Asia. The five Central Asian countries, Kazakhstan, Uzbekistan, Kyrgyzstan, Tajikistan and Turkmenistan is located in the hinterland of the Eurasian continent, subject to traffic inconvenience, the region's level of economic development lag behind East Asia and Europe. Along with the strategic concept of "Silk road economic belt" being proposed, Central Asia is expected to become the convenient channel connecting Asia and Europe, the investment in energy industry development, urban residential construction is correspondingly increasing, the demand for plates and timbering will be greatly improved, create unprecedented opportunities for Chinese iron and steel products to enter the Central Asia market [16]. However, Chinese iron and steel enterprises are in strong competition with Arcelor Mittal and Russia, Ukraine and Turkey steel enterprises, which use a customs union policy, trade protection, means to suppress China's iron and steel exports, made Chinese iron and steel enterprises' export environment deteriorated. For this situation, Chinese iron and steel enterprises can turn exports into building steel production bases in the Central Asian region, resolve the threat from the competitors. On the one hand, China has obvious geographical advantages, has closer economic and trade exchanges with the Central Asian region, has formed a friendly cooperative partnership, respectively China is Kazakhstan’s largest trading partner, Turkmenistan, Uzbekistan, Kyrgyzstan’s second largest trading partner, and the cultural differences are relatively small, relatively easy to conduct cross-cultural management, which build a good foundation for China iron and steel enterprises to enter the Central Asia market; on the other hand, the huge potential of steel consumption in Central Asia, the iron and steel enterprises can meet local strong market demand by establishing production bases, in addition, the Central Asian countries are rich in mineral resources, labor costs are relatively low, these also provide favorable conditions for the production of iron and steel. In a word, for Chinese iron and steel enterprises establishing production bases in the Central Asian region is not only an important part of the global strategic layout, but also be helpful for promoting implementation of “One Belt, One Road”, demonstrate great strategic significance.

\subsection{The Opportunities of Controlling the Trade Channels}

The development of iron and steel enterprise depends not only on the supply of upstream raw materials, also on the wide downstream consumption demand. At present, steel demand, steel prices continued to weaken, make the iron and steel enterprise' production and operating activities face enormous challenges, the competition among the iron and steel enterprises will not only be limited to cutting costs and technological innovation in production areas, the product market is gradually becoming an important factor influencing the development prospect of the enterprises, trade channels for the iron and steel enterprises is very important. In the new era of "channel is the king", the iron and steel enterprises implementing globalization strategy should broaden the ho- 
rizon, make efforts to control the trade channels, extend the steel industry chain and expand the scope of product circulation by the ways of building their own trading company, and cooperating with the international steel trading corporations.

\subsubsection{Building Their Own Trading Company Abroad}

$<2014$ African economic report> said that Africa's economic growth is good, GDP growth rate is expected to reach 4.7\% and 5.0\% in 2014 and 2015 [17], far more than 4.0\% in 2013, India, Brazil, ASEAN and other developing countries and regions also entered a period of accelerated development, infrastructure construction and industrial development will have a huge demand for steel, in the next few years, these areas will undoubtedly be fertile land for investment. Chinese iron and steel enterprises should seize the opportunity in the hot investment regions to building their own trading company or steel sales center abroad, simultaneously play the roles of producers and sellers, develop international trade business, expand sources of profit, and with a good after-sales service, strive to improve regional competitiveness and market share, to actively participate in the global competition. As is known to all, South Korea's Daewoo International Trading Company is in charge of POSCO' trade business as a subordinate enterprise, POSCO' steel exports are mainly realized by Daewoo International Trading Company, other steel enterprises such as Mittal Steel Company, JFE Steel Corporation, Tata Steel also hold their own steel trading company.

Back to the domestic view, taking Baosteel for example, in October 1993, it established Baosteel Europe Trading Company in Hamburg, Germany, unified management of Baosteel branches and trade in Europe, Africa and Middle East, with the business purpose of "relying on Baosteel, but not completely rely on Baosteel", the company has become a large German trading company, the operating performance and credibility of the company ranks first among German Chinese companies for many years [18]. And, it just is the one of many overseas trading companies of Baosteel, After many years of exploration, Baosteel grasped the opportunities of overseas trade, established a set of overseas trade system and sales network, set up many overseas trading company such as Baosteel European company, Baosteel America company, Baosteel Japan company, Baosteel Singapore Company and Several overseas branches, which not only for Baosteel brought abundant returns, but also greatly enhanced the strength of Baosteel in the competition of globalization.

Although building their own channels can improve the market share in the specific areas for the iron and steel enterprises, make more profit from the practice of globalization, but not all iron and steel enterprises can put into practice, the main reason is that the enterprises must achieve a higher standard in financial strength, management capabilities and so on. On the one hand building their own channels easily disperse enterprise resources, is not conducive to specialize in main business, To some extent it will weaken the enterprises' specialized production capacity; On the other hand the development of subsidiary business will expand the sources of risk and further increase the management risk of the enterprise. To avoid this situation, the iron and steel enterprises should first comprehensively consider their own financial strength, management capacity, human resources and trade business development potential, carefully make decision, after the establishment of trading companies should pay special attention to the analysis and research on market dynamics and potential risks, establish a set of early risk warning system Inside the enterprises, strengthen risk supervision. At the same time, the enterprises should especially pay attention to learning from professional steel trading company, draw lessons from the successful experience, understand each link of the trade process, and gradually optimize the trade operation, to play the positive role in the field of trade, and continuously enhance the overall competitiveness.

\subsubsection{Cooperate with International Steel Trader}

In addition to building their own trading company abroad, in hot investment areas such as Africa, India, Brazil and other regions, Chinese iron and steel enterprises can vigorously attempt the multiple cooperation with the international steel trader which own global sales network to control trade channels, the former focuses on production, has the advantages in the capital and technology, the latter has rich customer resources and broad marketing channels, the two can achieve complementary advantages through the establishment of partnership. The cooperation benefit of the iron and steel enterprises is mainly reflected in two aspects: reduce trade friction in exports of steel products, reduce business development costs, be easier to develop overseas markets; secondly, can deepen the understanding of international trade rules and trade process, and accumulate rich experience to develop their own trade department.

On November 18, 2014, Hebei Iron and Steel Group successfully held 51\% stock of Degao international trade 
holding company, smoothly realized the holding of the world's largest iron and steel trader and comprehensive service provider, it is the first time that Chinese state-owned steel mills go out to merge international steel trader. In current circumstances of market depression, the exploration provided a new idea for the overseas investment of Chinese iron and steel enterprises. Switzerland Degao was the world's largest iron and steel trader that occupied an important position in the world trade of steel, raw and auxiliary materials, Hebei Iron and Steel Group has the aid of Degao' worldwide abundant sales network to broaden sales channels of steel products, and effectively resolve the excess capacity, Degao can also obtain a stable upstream supply channels, and enjoy preferential treatment in terms of price.

\subsection{The Opportunities of Forming the Strategic Alliances}

Iron and steel industry has a high degree of industrial linkage, facing fierce international competition, the iron and steel enterprises and related enterprises can form partnership that shows a strong strategic significance: the establishment of strategic alliances within the industry can form Strategic joint force, while effectively dispersing the risks, improve the success rate of investment; forming the strategic alliances among different industries can strengthen the business penetration in other industries, make full use of their respective advantages to achieve complementary advantages.

\subsubsection{Industry Alliance}

The industry alliance mainly refers to establishing partnerships among the iron and steel enterprises, Chinese iron and steel enterprises in the internationalization process can not only form the strategic alliances with other domestic iron and steel enterprises alliance, "going out" together, also can cooperate with international largescale iron and steel enterprises, learn from their mature international management mode, draw lessons from the experience, improve the shortcoming. With the continuous development of the global steel industry, the competition within the industry is becoming increasingly fierce, in terms of large international steel companies, although they have a significant competitive advantage, but not be denied is that strict environmental regulations, the threat from steel substitutes are two major problems (refer with: Table 1), Chinese iron and steel enterprises are no exception. Combined with the actual development of domestic and foreign iron and steel industry, make full use of their respective advantages their respective advantages, establishing the industry alliance is an effective measure to solve two major problems. It is not difficult to find that these foreign iron and steel enterprises have the advantages in R\&D technology, Chinese iron and steel enterprises must achieve the advantages to adapt to the global competition. In the practice of globalization, Chinese iron and steel enterprises should pay attention to form the strategic alliances with the international iron and steel enterprises, jointly develop steel products that meet the requirement of new environmental law to reduce energy consumption and pollution, jointly

Table 1. The main business areas, strength and weakness of several international iron and steel enterprises.

\begin{tabular}{|c|c|c|c|}
\hline Company Name & Main business area & Strength & Weakness \\
\hline Arcelor Mittal & $\begin{array}{l}22 \text { countries in the America, } \\
\text { Europe, Asia and Africa }\end{array}$ & $\begin{array}{l}\text { Have the largest and broad market, } \\
\text { advanced technology research, strong } \\
\text { development ability }\end{array}$ & $\begin{array}{c}\text { Fierce competition, strict environmental } \\
\text { legislation, threat from alternatives to } \\
\text { steel }\end{array}$ \\
\hline POSCO & $\begin{array}{l}\text { South Korea, Japan, China, Asia, } \\
\text { North America and other regions }\end{array}$ & $\begin{array}{l}\text { Complete product category, wide } \\
\text { business scope, strong R\&D ability }\end{array}$ & $\begin{array}{c}\text { Be highly dependent on domestic } \\
\text { markets, heavy debt burden, threat from } \\
\text { alternatives to steel }\end{array}$ \\
\hline JFE & $\begin{array}{l}\text { Canada, Brazil, China, Thailand, } \\
\text { Philippines, Indonesia, South } \\
\text { Korea, Germany and the United } \\
\text { States, etc. }\end{array}$ & $\begin{array}{l}\text { Developed quality assurance system, } \\
\text { strong technical innovation ability, near } \\
\text { the emerging markets }\end{array}$ & $\begin{array}{l}\text { Be highly dependent on imported raw } \\
\text { materials, strict environmental } \\
\text { legislation, threat from alternatives to } \\
\text { steel }\end{array}$ \\
\hline EU steel industry & $\begin{array}{l}\text { Regional industry, } \\
\text { Multinational operation }\end{array}$ & $\begin{array}{l}\text { Grasp the high-end steel products within } \\
\text { the EU market, highly specialized, strong } \\
\text { R\&D ability, high degree of recycling }\end{array}$ & $\begin{array}{l}\text { Be highly dependent on imported raw } \\
\text { materials and internal market of EU, } \\
\text { high energy consumption, strict } \\
\text { environmental legislation, weakened } \\
\text { regional dominance }\end{array}$ \\
\hline
\end{tabular}

Source: Made by the author according to the relevant information. 
develop green iron and steel industry and assume the social responsibility of the enterprises, improve production process to enhance the quality of steel products, defuse the threat of the substitutes, strengthen cooperation for the common interests. At the same time, according to the specific conditions of the different enterprises, the formulation of strategic cooperation should meet respective need, for example, EU iron and steel industry has rich experience in the production of high-end steel products, but the gains from trade outside EU are obviously insufficient, Chinese iron and steel enterprises can establish strategic alliance relationship with the local enterprises, achieve a win-win and mutual benefit: (1) Chinese enterprises can expand exports of the low-end steel products to EU region, not only meet the local need, also be an effective solution to the problem of domestic overcapacity. (2) With the iron and steel industry restructuring and industry chain optimization and upgrading, the future demand for high quality steel will be enhanced. Therefore, the two sides can strengthen the production of high-end products, and with the help of broad international sales channels of Chinese iron and steel enterprises to expand the export of EU steel products.

Collectively, the benefits of establishing the industry alliance are mainly reflected in the following: (1) both sides obtain their own interests from the mutual cooperation, such as mastering advanced technology, trade growth in specific areas, enhancing international competitiveness, so as to promote the enterprises' global process. (2) Cooperate among the powers, make common efforts to solve common problems, promote the transformation and upgrading of the whole industry, promote the overall development of iron and steel industry in the world.

\subsubsection{Cross Industry Alliance}

In the case of rise of trade protectionism, Chinese iron and steel enterprises have been plagued by trade friction. In addition to actively participate in international trade negotiations, and strengthen the international communication, the iron and steel enterprises can build alliances with international trader, especially the trader owning sale channels in the export destination, to avoid international trade friction. In March 2013, Tangshan Iron and Steel Group came into the cooperation intention with Switzerland Degao, Tangshan Iron and steel company holds $10 \%$ shares of Degao company, both sides signed the structural financing agreement of steel products exports, guaranteed by Degao company, 12 Chinese and foreign bank, such as Deutsche Bank, ABN AMRO Bank, Bank of China, one-time prepay $\$ 1.2$ billion loans to Tangshan company, support the production of the international best-selling steel products in Tangshan Iron and Steel Group [19], this is useful to defuse anti-dumping and countervailing situation Chinese steel products encountered repeatedly.

It is the necessary ability that Cultivating globalization thinking, keeping keen insight into market opportunities for the iron and steel enterprises which participate in global competition. Facing the weakened global economic growth, continuous increase of production capacity, corporate profits being squeezed, POSCO committed to increase investment in emerging markets, which follows the downstream customers to set up new projects [20], Similarly Nippon Steel as the leader of the car plate production quickly adjusted the strategy, according to the development of downstream users accelerated the investment layout in emerging markets in the overseas automobile steel production system to enhance its competitiveness [21]. Taking "One Belt, One Road" construction and China's steel overcapacity into account, Chinese iron and steel enterprises should seize many opportunities that "One Belt, One Road" provides, find a suitable path for its development goals. In addition to the increase in steel exports to the regions, Chinese iron and steel enterprises can further enter local steel consumption market through strategic alliances; establishing strategic alliance with some end users of steel is conducive to realize their own economic interests. As the important areas along Silk Road Economic Belt, in recent years the automobile, shipbuilding, home appliances and electronic industry is booming in the Southeast Asia and South Asia, the demand for steel continually grows, steel gap continually be expanded. Take the automobile market for example, the private car market of many developing countries in the area has broad development prospects, the global automotive manufacturers actively strengthen their investment in the next few years, automotive steel will increase significantly, Chinese iron and steel enterprises can carried out close cooperation with automobile manufacturers, on basis of the establishment of strategic alliances, jointly develop corrosion resistance, abrasion resistance, high pressure, high quality steel, optimize the product structure, improve product quality, enhance the ability of research and development of new products, sign a long-term car plate supply agreement with the automobile companies, and strive to improve the after-sales service system, which can bring stable and substantial revenue, also can enhance the level of understanding of the related industries and penetration force, and continuously enhance the comprehensive competitiveness. 


\subsection{The Opportunities of Establishing the Overseas R\&D Centers}

On April 9, 2011, Baosteel-Australia Joint Research Center was established in Brisbane, Australia, which is the first overseas joint research and development center Baosteel set up, as the leader in Chinese iron and steel industry, the measure of Baosteel showed significance to other Chinese iron and steel enterprises, setting up overseas $R \& D$ center is an important way to improve the international competitiveness following the establishment of the overseas production bases. Chinese iron and steel enterprises should not be limited in the fixed mode of development of labor-intensive and resource intensive industries, more efforts should be made to seek a breakthrough, pay attention to knowledge, talent and technology, to move closer to the knowledge and technology intensive industries. As shown in Table 2, in the global development process, Chinese iron and steel enterprises try to establish R\&D bases in the main markets, accelerate the new products and quality products development process, and promote product upgrading.

R\&D internationalization is the necessary mean for multinational companies to strengthen the global competition ability [22], establishing overseas R\&D center is conducive to the formation of "global collaborative R\&D system”, realize the free flow and effective allocation of global R\&D resources, obtain the greater competition benefits, be conducive to the formation of comparative advantages.

\section{The Implementation Frame of Chinese Iron and Steel Enterprises' Globalization Strategy}

In 2015, the global steel industry continues the basic situation in 2014, the recovery is still weak in short term, under such international background, overcapacity, steel price decline are still two problems which constraints the development of Chinese iron and steel enterprises. In order to meet the challenges and realize the dream of iron and steel power, Chinese iron and steel enterprises should vigorously implement the strategy of globalization, tap and grasp the opportunities of global investment, accelerate the overseas investment. The above analysis of five overseas investment opportunities is a reference, Chinese iron and steel enterprises can further implement the globalization strategy, the strategic implementation frame is shown in Figure 4.

The implementation frame of Chinese iron and steel enterprises' globalization strategy shows the main conclusions of this paper: (1) at present, for Chinese steel enterprise, the overseas investment opportunities include resource investment, strategic cooperation, the global strategic layout and setting up R\&D center and so on, the enterprises can combine their competitive advantage with the future development target, target market and overseas resource status, make prudent investment decisions; (2) there is a complementary relationship among

Table 2. The opportunities and measures of Chinese iron and steel enterprises to establish overseas R\&D center.

\begin{tabular}{|c|c|c|}
\hline & The developed countries and regions & Emerging markets \\
\hline Representatives & The United States, Japan, Australia, Europe, etc & $\begin{array}{l}\text { India, Brazil, South Africa, the association of south-east } \\
\text { Asian nations (ASEAN), etc }\end{array}$ \\
\hline Opportunities & $\begin{array}{l}\text { - There are many universities and scientific research } \\
\text { institutes in the world; } \\
\text { - The globalization degree of iron and steel enterprises } \\
\text { is high and the production technology is advanced; } \\
\text { - The economic development degree is high, so the } \\
\text { demand for high-end products is huge.. }\end{array}$ & $\begin{array}{l}\text { - The economic development and the construction of } \\
\text { infrastructure speed up, the demand for steel products } \\
\text { is more and more enormous; } \\
\text { - The development of downstream industry is potential; } \\
\text { - Be rich in human resources, the labor costs is low. }\end{array}$ \\
\hline $\begin{array}{l}\text { The proposed } \\
\text { measures }\end{array}$ & $\begin{array}{l}\text { - To strengthen the cooperation with local universities, } \\
\text { research institutes, forming model of "industry- } \\
\text { university-research" cooperation; promptly } \\
\text { understand the latest technology trends in the } \\
\text { industry, research and develop new materials, new } \\
\text { technology, new energy saving measures, etc; } \\
\text { - Guided by the demands of users, focusing on value } \\
\text { creation, provides the high quality product and } \\
\text { material solutions, meet customer demand for } \\
\text { heterogeneous products. }\end{array}$ & $\begin{array}{l}\text { - Research on green steel technology, produce high } \\
\text { strength, low energy steel products, reduce the threat } \\
\text { from substitutes; } \\
\text { - To cooperate with the downstream industry, research } \\
\text { and develop products to adapt the market demand, } \\
\text { extend the steel industry chain; } \\
\text { - Introduce overseas elite, to speed up the international } \\
\text { flow of talent, strengthen the cultivation and reserve of } \\
\text { the scientific and technological personnel. }\end{array}$ \\
\hline
\end{tabular}

Source: Made by the author according to the relevant information. 


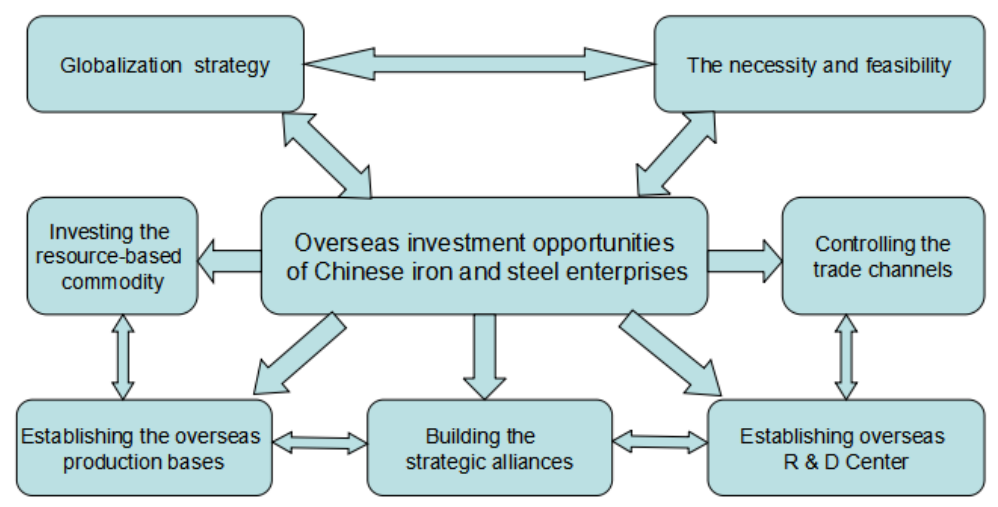

Figure 4. The implementation frame of globalization strategy.

the investment opportunities, the enterprises can comprehensively consider the investment opportunities and future development prospects in overseas investment decisions, in order to achieve the strategic goal of globalization.

Although the current overall steel industry situation is discouraging, but the increasingly open global market provides a broad development space for iron and steel enterprises. Therefore, Chinese iron and steel enterprises should be confident and firmly implement the strategy of globalization, adhere to the path of globalization, pay close attention to the overall trend and market changes, make efforts to grasp the overseas investment opportunities, integrated global resources, grow into real multinational corporations, constantly make new progress of globalization.

\section{References}

[1] Wang, J.J. (2010) International Business Case Analysis of Chinese Enterprises. China Market Press, Beijing.

[2] Han, X.G. (2004) Thinking about the Economic Globalization and China Petroleum Group’ Globalization Strategy. Academic Journal of Beijing Petroleum Management Cadre Institute, No. 3, 27-31.

[3] Jindal, D. and Jee, C. and Thakur, R.R. (2011) Nissan: Go-Global Strategy. Business Strategy Series, 12, 195-201. http://dx.doi.org/10.1108/17515631111155151

[4] Govindarajan, V. and Gupta, A.K. (2008) The Quest for Global Dominance: Transforming Global Presence into Global Competitive Advantage. Jossey Bass, 20-21.

[5] Cao, X.Q. and Lai, Y.W. (2012) Chinese Iron and Steel Enterprises” “Going Out” Route and Policy Recommendations. China Development Observation, No. 7, 16-18.

[6] Zhang, X.X. (2013) The Challenges of Global Steel and the Way Out of China Iron and steel. China Metallurgical Newspaper, 2013-11-02.

[7] Xiang, B. (2007) What Is Baosteel Going to Learn from Mittal. Management and Wealth, No. 5, 42-44.

[8] Xu, S.B. (2014) Analysis on Developing Feature of POSCO and Its Enlightenment to Baosteel. Metallurgy Management, No. 6, 31-36.

[9] Ayodele, T. and Sotola, O. (2014) China in Africa: An Evaluation of Chinese Investment. IPPA Working Paper Series.

[10] Dong, Y. (2014) Trends in Global Trade Rules and China's Opportunity. International Economic Review, No. 1, 45-64.

[11] IBM Institute for Business Value (2006) Going Global: Prospects and Challenges for Chinese Companies on the World Stage. IBM Business Consulting Services.

[12] A Slump in the Mine Prices Caused the Impact to the Small and Medium Mines in Australia. Steel Union Information. http://info.glinfo.com/14/0910/05/AD9C3C253C915DA0.html

[13] Focus on African Iron Ore Resources - to Seize the African Iron Ore, Ease the Supply Pressure of Raw Materials. My Steel Network. http://www.mysteel.com/topic/jif

[14] Yuan, Y.F. (2014) Africa, the Place of Future Steel Opportunities. China Metallurgical Newspaper, 2014-06-01.

[15] Foster, V. and Briceño-Garmendia, C. (2010) Africa’s Infrastructure: A Time for Transformation. A Copublication of the Agence Française de Développement and the World Bank. 
[16] Liu, Y. (2014) Marketing Strategy for Exporting Xinjiang Steel to Central Asian Market. Foreign Trade, No. 6, 24-25.

[17] 2014 Africa Economic Report Calls for African Countries to Accelerate the Industrialization. http://paper.chinahightech.com/html/2014-08/18/content_8645.htm

[18] Annual Report of Baosteel. Http://www.baointl.com/company/dept_company02_2001_13.htm

[19] Capacity Internationalization Hebei Iron and Steel Intends to Hold the World's Largest Steel Trade Provider. China News Network, 2014-09-16.

[20] Zhang, X.X. (2013) POSCO’ Overseas Downstream Investments Aim the Upstream Supply of Raw Materials. China Metallurgical Newspaper, 2013-04-09.

[21] Zheng, R. (2013) Analysis on Posco and Nippon Steel’ Automobile Plate Overseas Production and Processing System Layout. Chinese Society for Metals. The Ninth China Iron and Steel Annual Meeting Proceedings. Metallurgical Industry Press, Beijing.

[22] Chen, Y.G., Han, B.T. and Li, Y. (2011) Review of Foreign Research on R\&D Internationalization of Multi-National Corporation Based on the Perspective of Knowledge Flow. Scientific and Technological Progress and Countermeasures, No. 16, 156-160. 